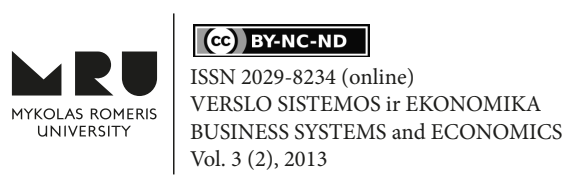

\title{
DYSFUNCTIONS AND RISKS OF BIG FINANCIAL INSTITUTIONS
}

\author{
Piotr MASIUKIEWICZ \\ Warsaw School of Economics \\ Al. Niepodleglosci 162, 02-554 Warszawa, Poland \\ E-mail: piotr.masiukiewicz@wp.pl, \\ Pawel DEC \\ Warsaw School of Economics \\ Al. Niepodleglosci 162, 02-554 Warszawa, Poland \\ E-mail: paweldec@gmail.com \\ doi:10.13165/VSE-13-3-2-06
}

\begin{abstract}
The recent economic crisis has shown that even very large companies, such as giant-sized business and seemingly unimaginable total assets, may fall. The authors put the research objective, which was to examine the characteristics of management in large financial companies and banks, according to the criteria adopted in the theory of praxeology and to identify the main risks and dysfunction, as well as risk mitigation instruments in this field. It is significant that the escalation of threats arising from the existence of systemic risk is a feature of modern financial markets. This paper examined in detail the theoretical aspects of large companies and the risk of financial market activity.
\end{abstract}

Keywords: crisis, risk, praxeology criteria, financial institutions, large structure.

JEL Classification: E5, E6, G32.

\section{Introduction}

After the recent international financial crisis has taken a broad discussion (involved in the academia, government experts, the European Commission, etc.), concern for the size of business, particularly in the financial markets, has grown. Basic criticism was directed towards the doctrine of too big to fail and too important to fail. The result of the analysis and international reports was to impose a partial responsibility for the crisis and gradual introduction of spec-regulation for large financial institutions within the European Union and the United States.

The purpose of this paper is to analyze the characteristics of management in big financial companies in accordance with the criteria adopted in the theory of praxeology and to identify the main risks and dysfunction, as well as instruments to reduce and minimize the risk in this regard. The paper also provides illustrative examples of financial institu- 
tions that are subject to special regulations. In the study, the authors used a foreign research (desk research), as well as conducted their own research. An important limitation of the study was the difficulty in accessing information on decision-making at the highest levels of management in large organizations (especially financial institutions). However, the authors sufficiently managed to reach the target group of managers, whose responses proved to be extremely valuable in studies and allowed the presentation of research results.

\section{Theoretical aspects of large structures}

The increased interest in large corporations emerged after the subprime crisis, during which the largest companies went bankrupt. In economic theory, little attention is dedicated to the problem of the optimal size of the enterprise. The relation between size and efficiency of the company is one of the most serious problems of economic theory. According to Knight, the possibility of achieving monopoly profits the company with providing a strong incentive for continued expansion, which must be balanced by other comparable action to reduce its effectiveness (Knight, 2006). In the theory of domination enterprises (F. Perroux), it is assumed that the company strives to achieve the greatest strength (power) in the economy and increase in a foreign company is resisting the force of other companies. This theory recognizes that the strength of enterprises in the economy, although it can be used to defend or even strengthen the position of inefficient enterprises, is very often a positive impact on the economy. There is, however, a comprehensive account of the costs and economic and social benefits to justify this claim.

Little attention to this issue was dedicated by Stigler (Nobel Prize Laureate in 1982). $\mathrm{He}$ is considered a pioneer of information economics and economics of regulation. He is the author, who analyzed the desired size of the enterprise and came to the conclusion that it is difficult to speak of a simple rule to determine it (Jasinski, 2008). He formulated the theory that studies should use the principle of survival of the company (the survivor principle), the group of companies, which is performing the best in the market in the long run. There was a need to determine what factors were critical to the survival. Drucker and representatives of the so-called current scheme developed the theory of the survival. The advantages of large entities were mentioned in the publications of the 90s. These advantages, amongst others, included the following: resistance to crises, the process of consolidation was considered a modern direction of change, economies of scale, standardization and internationalization of products, greater potential for innovation, investment in innovation and change in quality of human capital and client access to the property in many parts of the world. Consolidation, globalization and standardization were considered to be the direction of modern changes in the business, including the financial markets. The last subprime crisis led to questioning the benefits of major players in the international market. The size of assets of certain entities was proven to exceed the GDP of the country - the seat (Masiukiewicz, 2012).

A comprehensive critique of large corporations in today's markets was conducted by Galbraith. He pointed to the often decisive role in shaping public purposes (in accordance with their needs), a significant influence on politics and finally the formation and control of demand and prices. He stated that "In the real world, the production company and the industry is moving to pricing and demand determine, by means of a monopoly, oligopoly, product design and highlighting, and other sales promotion. It is recognized even in or- 
thodox economic terms." (Galbraith, 2005, p. 21). The risk of over leverage is a particularly important problem in financial management. It was discussed in various works by, amongst others, Galbraith, Roubini, Stiglitz, Toporowski (Stiglitz, 2010). Lever can be operated without negative financial consequences as long as the company has a sufficient amount of shortterm or liquid financial assets in respect of loans taken out for an extended period of time. If the financial markets suddenly become illiquid (as it happened in the recent crisis), the reason of it could be that the company does not have enough liquid assets to keep the lever (Toporowski, 2012). Firms in this situation try to deleverage, i.e. to reduce its debt. Pruning ordinary (not on financial goals) spending, which is one of the ways to reduce its debt, triggers a process of debt deflation that Fisher believed to be the essence of the economic crisis. In this way, the entire balance is stripped of the financial system. Toporowski considers it as a result of deleveraging of suffering losses and it is the most important mechanism for the spread of the crisis in the economy (Toporowski, 2012). However, this view is controversial: first, the authors do not take into account the phenomenon of over crediting (overleverage), which is more harmful to businesses and the economy, and, secondly, they do not notice other outside sources of funding loan growth (see Table 1). In the analyses of the recent financial crisis, subprime world economists took into account the problems of financial institutions on the basis of the doctrine of TBTF and TITF (Cecchetti, 2008; Norton, 2009; Roubinii, Mihm, 2011; Stiglitz, 2010). Gup, Mishkin, Molyneux, Stern and Feldman pointed in their analyses that the risk of moral hazard is placed on top-managers, who have received aid for bankrupt banks (Gup, 2004; Mishkin, 2006; Gardner, Molyneux, 1998; Stern, Feldman, 2004). On these issues in the context of high financial leverage, as highlighted in the report by Larosiere, which was adopted as an official document of the European Commission, specifying the post-crisis reform, Fisher, the president of the Dallas Fed, in his communication to the U.S. Congress said that "The financial institutions regarded as too big to fail, they should be restructured in a number of operating units. (...) They use state guarantees and are not controlled by the fragmented shareholders, so take the chance to increase profits without bothering about the consequences." (Szczygiel, 2013, p. 45).

Table 1: Key business risks related to financial leverage

\begin{tabular}{|c|c|c|c|}
\hline No. & Financial Risks & No. & Behavioral Risks \\
\hline 1 & $\begin{array}{l}\text { Termination of financing agreement before the } \\
\text { deadline or no roll } \\
\text { Request of additional security for a loan }\end{array}$ & 2 & $\begin{array}{l}\text { The loss of credibility in the market to } \\
\text { suppliers and customers and the related } \\
\text { loss of access to sources of financing } \\
\text { Loss of confidence of stakeholders }\end{array}$ \\
\hline 3 & $\begin{array}{l}\text { A sudden drop in the market value of the is- } \\
\text { sued securities (bonds, derivatives) }\end{array}$ & $\begin{array}{l}3 \\
4\end{array}$ & $\begin{array}{l}\text { Deterioration of credit ratings } \\
\text { Adverse changes in the company's image }\end{array}$ \\
\hline 4 & Termination of revolving credit extension & 5 & Psychological effect of the loss of market \\
\hline 5 & $\begin{array}{l}\text { A sudden increase in the price of money that } \\
\text { causes so. debt trap }\end{array}$ & 6 & $\begin{array}{l}\text { share (about word of mouth) } \\
\text { Risk taking procedures bankruptcy law }\end{array}$ \\
\hline 6 & Foreign exchange risk & 7 & Other \\
\hline 7 & The financial crisis resulting in a domino effect & & \\
\hline 8 & Other & & \\
\hline
\end{tabular}

Source: Masiukiewicz, P. (2012) 


\section{Dysfunctions in terms of praxeology}

This section examines the most important aspects of operation of large companies according to the criteria of the theory of praxeology.

A. Rationality. Weber argued that rationality is revealed in selecting the most effective means to achieve a goal. However, the question arises whether the rationality of the choice of objectives and selection of effective implementation is possible. Empowerment of individual, parts of large entities to differences in the assessment of reasonableness of their actions is also included in the aspect of rationality. Translated into action, the rule of rationality always takes place under certain conditions (political, economic, organizational, cultural) and is variable. This means that rationality cannot be absolutized. The theory of bounded rationality is fully applicable here. Information asymmetry, moral hazard or corruption when deciding flawed incentive systems created a string of irrational decisions in large corporations leading to bankruptcies (Enron, WorldCom, Arthur Andresen, Lehman Brothers, etc.) (Pasieczny, 2012).

B. The efficiency of the large companies. Effectiveness criterion achieves the temporal efficiency and saving of financial resources (Kotarbinski, 1973). Views on the efficiency of the corporation are different here. Amongst these views, pathology in large organizations indicates overstaffing, waste of resources, information noise, chronic decision systems, environmental degradation, etc. Published analysis of the failures of large, global companies indicates a lack of management skills (i.e. Enron, WorldCom, Northern Rock, AIG, etc.) (Philips, 2011).

C. Effectiveness. In large companies (holding companies), the growth of bureaucracy and control of the costs of levelling generate economies of scale. But the large structures have the advantage dictates of the suppliers (raw materials, materials, services) - centralized purchases give bargaining power. Cost competitiveness of these entities is beyond dispute. Case study analysis about corporate bankruptcies in the recent subprime crisis indicates low effectiveness (Masiukiewicz, 2010).

D. The precautionary principle formulated by Kotarbinski in the context of the activity was often broken in practice of the operations of large corporations. Excessive risktaking resulted in many bankruptcies in subsequent crises.

E. Competitiveness. There is a natural tendency of large companies for further development (including steps through the processes of M\&A) and the appropriation of the largest part of the market. The effect of gigantism has many social consequences, which creates oligopolies and destroys the competition. A classic example is the LCD TV market (6 global companies) and the PC market. At the same time, modern marketing, including neuromarketing, offers powerful instruments of how to affect the attitudes of buyers.

F. Economies of scale. Complexes are defined by Kotarbinski as "any object made, all of which together form a whole due to the operation of a common goal, whether it is understood in the sense of phraseological, whether in the biological sense, (...). Well, for such an object composed threatened constantly destructive factors and takes it as such only under the tutelage of exceptional conditions favourable or protective measures" (Kotarbinski, 1973, p. 203). Benefits of the economies of scale 
can be viewed according to the criterion of consumer benefits and social benefits (Masiukiewicz, 2010). Regard to social benefits is extensive in the criticism of large global enterprises (Altman, Roubini, Stiglitz, etc.).

G. Ownership and management. In large business entities, alienation managers, owners and boards are often shaped by the so-called strategic shareholder (Urbanek, 2012). Goals set by such owner are often short-term in nature (related to its interests), and huge bonuses under the incentive ensure their implementation by topmanagers. Because of the fuzzy responsibility, the principle of the right becomes a pervasive error (e.g., only few lawsuits against the managers of the subprime crisis have been filed). Weaknesses in corporate governance were cited as the cause of a number of corporate bankruptcies in the last crisis (Urbanek, 2012; Masiukiewicz, 2011). Global companies are getting out of control state too much.

H. Surviving as a target. The main goal of many organizations is a long-term survival in the market (see theory by Drucker). For large companies, their owners and topmanagers, crisis is a struggle for existence at all costs, including the fight for state aid (bailout). Despite this, many large corporations do not survive crises (such as the Japanese crisis, the dot.com crisis, the subprime crisis).

\section{Big companies and their values and benefits}

Large corporations prefer their business values to be not always consistent with the expectations of customers and society, as it has been confirmed by international studies. Extensive study of the recognized and preferred values as a basis for action in the market was carried out by a network of professional services firms called ECCO Network in 12 countries worldwide, including major corporations just before the outbreak of the subprime crisis (ECCO, 2006).

The study was conducted in 2006 among 4,000 companies in 14 different industries. It showed that the moral values of self-fulfilment and social values to large enterprises attach the least importance and it is regarded as disturbing (see Table 2). The antidote to these problems was based on the management approach to corporate social responsibility. There are, however, studies and analyses indicating minimalism and superficiality programs in corporate social responsibility.

The values include the foundation of the management of each institution. It is possible that the wrong value systems were the cause of the crisis in some companies. Today, larger studies are needed for the changes in the system of consequences for business success.

The advantages of large entities were mentioned in the publications of the 90s. Among many others, these publications included the following topics: resistance to crises, the process of consolidation was considered a modern direction of change, economies of scale, standardization and internationalization of products, greater potential for innovation, investment in innovation and change in quality of human capital and client access to the property in many parts of the world. Consolidation, globalization and standardization were considered to be the direction of modern changes in the business, including the financial markets. The last subprime crisis led to question the benefits of major players in the international market. The size of assets of certain entities exceeded the country's GDP - the company's headquarters. 
Table 2: Preferences of large companies in the area of regarded value

\begin{tabular}{|c|c|c|c|}
\hline No. & $\begin{array}{l}\text { Group of } \\
\text { values }\end{array}$ & Details & $\begin{array}{c}\% \text { of } \\
\text { responses }\end{array}$ \\
\hline 1 & $\begin{array}{l}\text { Professional/ } \\
\text { skills values }\end{array}$ & $\begin{array}{l}\text { Confidentiality, customer satisfaction, determination, efficiency, } \\
\text { perfection, internationalism, expertise, management, practicality, } \\
\text { professionalism, quality, reputation, service, solvency, speed, spirit } \\
\text { of cooperation, create value, etc. }\end{array}$ & 40,0 \\
\hline 2 & $\begin{array}{l}\text { Winning } \\
\text { values }\end{array}$ & $\begin{array}{l}\text { Ambition, anticipation, competitiveness, courage, entrepreneurial } \\
\text { spirit, fighting spirit, initiative, innovation, success, etc. }\end{array}$ & 21,0 \\
\hline 3 & $\begin{array}{l}\text { Behavioral } \\
\text { values }\end{array}$ & $\begin{array}{l}\text { Adaptability, authenticity, attractiveness, availability, penetration, } \\
\text { dignity, freedom, humility, individuality, inventiveness, employee } \\
\text { involvement, modernity, openness, passion, patience, requiring the } \\
\text { other, responsibility, tradition, etc. }\end{array}$ & 12,0 \\
\hline 4 & Society values & $\begin{array}{l}\text { Environment, health, survival, division, corporate social responsibi- } \\
\text { lity, sustainable development. }\end{array}$ & 9,0 \\
\hline 5 & $\begin{array}{l}\text { Relational } \\
\text { values }\end{array}$ & $\begin{array}{l}\text { Availability, communication, confidence, sociability, harmony, par- } \\
\text { tnership, respect, etc. }\end{array}$ & 7,0 \\
\hline 6 & Moral values & Ethics, the imitation of nature, integrity, loyalty. & 6,0 \\
\hline 7 & $\begin{array}{l}\text { Self-fulfilment } \\
\text { values }\end{array}$ & Humanism, personal development, fun, talent. & 3,0 \\
\hline 8 & Social values & $\begin{array}{l}\text { Equality, democracy, justice, inclusion, reciprocity, patriotism, plu- } \\
\text { ralism, etc. }\end{array}$ & 2,0 \\
\hline
\end{tabular}

Source: ECCO (2006)

The following facts indicate the specified major defects in large structures:

- Limiting the independence of consumers and competition destroys small businesses;

- Effectiveness varies, sometimes being not different from small businesses and creative accounting;

- Dysfunctions and pathologies of organizations, including the creation of additional costs;

- Noise information and irrationality decision;

- Distorted incentive systems for top-managers;

- Not giving up bankruptcy procedures (rules and TITF and TBTF);

- Defects of corporate governance and management to the alienation of property.

Further advantages of large corporations are becoming a myth. In 2013, Deloitte conducted an analysis of the Top 500 companies operating in Central and Eastern Europe. Over $40 \%$ of respondents from year to year indicate that financial performance is getting worse and there is a lower resistance to the crisis (Deloitte, 2013). The U.S. Senate condemned few corporations (Google, Apple, Marks \& Spencer) for evasion of taxes. Under the influence of social criticism, the Belgian government is considering a spec-tax for large corporations, the so-called Tax fairness (fairness tax or minimum tax).

The Dodd-Frank Act in the U.S. introduced a provision authorizing the Fed to put on the list of major corporate strategic financial security, all of which it considers important for safety.

An open question still remains whether and how broadly the activities of large corporations should be regulated. 


\section{The risk of major players in the financial market}

Escalating threats arising from the existence of systemic risk is a feature of modern financial markets. Creation of large global institutional structures and financial groups (including holding companies and conglomerates) resulted in the emergence of a number of consequences of the risk management system (Zygierewicz, 2011):

- More and more banks are getting bigger and contain numerous transactions in the global market with entities of similar size (banks and quasi banks), creating in effect a network of links, which can progress rapidly to crisis contagion channels (contagion effect);

- Created institutions referred to in the literature as being too big to fail (TBTF) or too important to fail (TITF) and their failure would have a serious negative impact on an international scale;

- The dynamic development of quasi banks (without adequate regulation and supervision), banks must pass on part of their activities to such corporations;

- Large global financial groups increasingly difficult to undergo surveillance as corporate and state-owned, and the interests of management, shareholders and customers (investors) have been divergent.

In the European Union, Switzerland and Japan, banks, which are too big to fail, have a large share in the banking sector of the country, and in some cases the value of their assets exceeds the GDP of the country offices. In Iceland, three banks fell in the recent crisis (i.e. $100 \%$ of the domestic banking system), resulting in de facto bankruptcy of the country. Also, in the European Union, banking sector assets before the crisis amounted to $350 \%$ of GDP in the EU (Szczygiel, 2013). Tarashew, Borio and Tsatsaronis listed three factors of systemic risk and systemic importance of individual financial institutions. Firstly, there is a risk of a single institution measured probability of bankruptcy. Secondly, there is the degree of concentration of large institutions in the financial system, and thirdly, there is the amount of exposure of the entity referred to as the total size of the systemic risk (as a result of a similar scope of activities of the various institutions, such as lending to the same industry or business linkages between entities).

The conclusions of the analysis carried out by the above mentioned authors are as follows:

- The contribution to the total body of systemic risk grows faster than linearly with the size of the company and increases its market share;

- Greater contribution to systemic risk generates those, which activity profile is close to the average profile observed in the financial sector;

- An important role is played by the interrelationship between financial institutions a relatively small exposure to the risk of financial institution with respect to nonfinancial entities may have little importance in comparison with the existence of a large exposure to other financial institutions in the interbank market;

- Interactions between the above mentioned factors play a major role.

Policy based on the doctrine of too big to fail (TBTF) or too important to fail (TITF) is based on the existence of large banks, the failure of which would cause turmoil in the market (Masiukiewicz, 2012). In this case, the state is ready to assist the institution, despite carrying liberal policy based on the open market. Therefore, there is a possibility to talk about political governments and international organizations in relation to the institutions too systemically 
important to fail, i.e. SIFI (Systematically Important Financial Institution). A list of such institutions for monitoring and conducting stress tests were developed in the EU (Cochiti, 2012).

An extensive discussion in many countries and international institutions on the regulation of large financial structures found among other things were reflected in the IMF document. The Fund is of the opinion that the financial sector reform should solve the problems of the risk created by large and complex financial institutions. A large part of the world's financial transactions goes for the small group of those bodies, with increasing inter-linkages internationally (IMF, 2010). International reports of post-crisis conducted by Volcker, de Lousier and Likened clearly show the risk of major financial institutions and the need for special regulation. In the report done by de Larosiere (official document EC), it has been concluded that there is a very large asymmetry between the benefits from the operation of large banks and the cost of their bankruptcy. Another problem is the cost of cross-border bank failure for the host country (branch, subsidiary bank).

At present, there is a number of negative characteristics of great financial structures, and among other things, the following ones are the most important (Freeman 2011):

- The multiplicity of causes of action areas involving many specialized state supervision are difficult to monitor on an international scale;

- There is a higher risk taken in some areas of the large banks and defective systems of motivation;

- Lack of transparency and substantial diversification to limit the effectiveness of corporate governance;

- Lack of transparency in accounts and structured products; problems for audit and rating;

- Not giving up bankruptcy procedures (TBTF and TITF doctrines) in this issue of the international division of costs of cross-border insolvency;

- Bureaucratization of activity, low controllability and complexity of the operation and political connections.

According to the International Committee on Banking Supervision in Basel, systemically important banks should have the ability to absorb losses at a level, which is higher than what is normally required of all banks, which requires, among others, identification of systemically important financial institutions (Zygierewicz, 2011). This policy on the size of banks has been implemented in the U.S. The Volcker rule, which includes sets (Dodd-Frank Act) that the financial institution should not have more assets than the assets of $10 \%$ of the sector (as a result of processes of M\&A) has been implemented. The EU has introduced the spec-regulation of large banks, and in some European Union countries, bank levy only for the largest banks (Masiukiewicz, 2012). Stiglitz negatively assessed the specific regulation addressing the major banks (Stiglitz, 2010). He suggested the following solutions:

- Division companies of too big to fail;

- A significant reduction in operations of large structures;

- Calibration restrictions as to the level of deposit insurance;

- Calibration requirement of capital adequacy;

- Standardize the system of motivation of top-managers.

Also, in the post-crisis to the latest report of the European Commission's proposal formulated by Liikanen, there was a segmentation of the largest global banks (Kasiewicz et al., 2013). 


\section{Social expectations and risks in the light of research}

Social expectations to large corporations, employing the most prominent managers, are high. They concern not only lower prices and high quality products, but also corporate social responsibility and ethics. Hence, the deep disappointment and violent public reaction exist to the recent financial crisis. Exemplification of that were demonstrations against the banks in the City, the Outraged movement in Western Europe and the USA, amongst others. A unique study called Environics Millennium Poll on the role of large corporations in society carried out in 23 countries identified completely new values that consumers preferred in relation to large corporations (see Figure 1). Expectations of higher ethical standards were very high.

Figure 1. Views on the role of large corporations in society

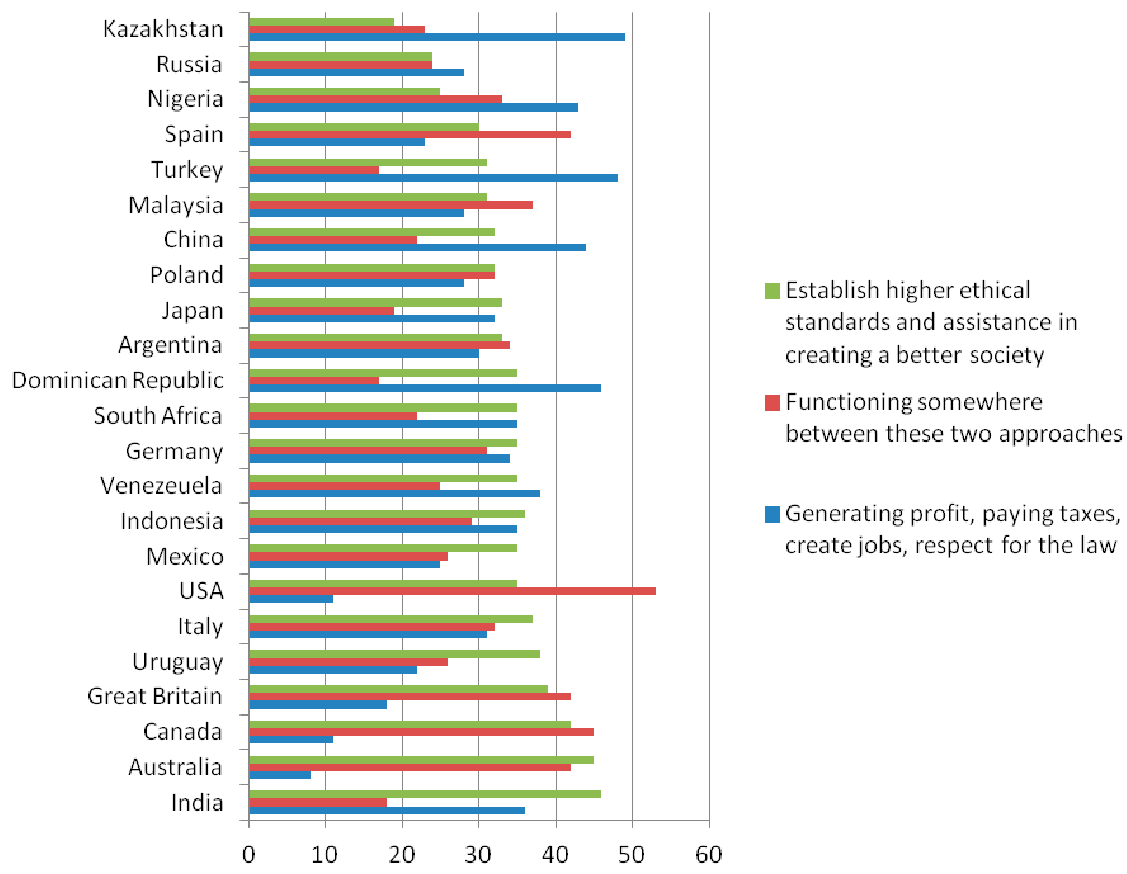

Note: The test was done in 1999 during an interview with 25 thousand respondents in 23 countries ( 6 continents). The study was co-financed by the Prince of Wales Business Leaders Forum and the Conference Board.

Source: Environics International (1999)

Studies conducted in Poland on the basis of expert opinion (Delphi) regarding the risk assessment of large financial institutions and the reasonableness of the use of special instruments for these institutions. It has shown that they estimate the risk as being high (86\% of respondents). In 2012, a study was conducted among 43 experts, professors and prominent practitioners of banking and finance, by the Delphic panel (agility polls 71\%). The aim of the study was to assess the risk of large financial institutions, identification of crisis contagion channels, 
the legitimacy of regulations and instruments limiting their operation (Masiukiewicz, 2012). Respondents of the survey were asked about the preferred instruments for large institutions. Regarding the question of limiting the increase of large banks (as a result of leverage standards), an appropriate instrument proved to be fight back the vast majority of experts, because nearly $75 \%$ of the respondents said yes (see Table 3). Most of the respondents felt that other financial institutions besides banks should have established a standard of financial leverage, which is shadow banking. Almost $70 \%$ of the respondents considered the separation of deposit and lending activities and investment banking entities to separate an appropriate instrument fight back as an appropriate business model against the banking tax as an instrument of risk mitigation spoken by most experts. What regards specific measures of systemic risk, a few asked about the new ones that are being implemented in the European Union. However, it was not asked quite clear and instruments already deployed as growth capital requirements and countercyclical capital buffer. Almost half of the respondents believed that all banks should be subject to stress tests and the minority of the respondents stated that cross-border operations should be controlled by international supervision. As many as $56 \%$ of the respondents said they support the proposal to establish a fund bankruptcy and reorganization processes in the European Union, which, however, does not correlate with negative responses on bank tax (its goal would be to finance such a fund) (Masiukiewicz, 2012).

Table 3: Reviews on risk mitigation instruments in global SIFI's

\begin{tabular}{|c|c|c|c|c|}
\hline No. & $\begin{array}{c}\text { Question } \\
(\mathrm{N}=43) \text { Answers w \% }\end{array}$ & Yes & No & $\begin{array}{c}\text { No } \\
\text { opinion }\end{array}$ \\
\hline 1 & Should global banks be supervised by special international supervisors? & 83,7 & 9,3 & 7,0 \\
\hline 2 & $\begin{array}{l}\text { Is limiting the growth of large banks (as a result of leverage standards) } \\
\text { an appropriate instrument of fightback? } \\
\text { - No response }\end{array}$ & $\begin{array}{l}74,4 \\
(2,3)\end{array}$ & 16,3 & 7,0 \\
\hline 3 & $\begin{array}{l}\text { Should other financial institutions outside the banks have established a } \\
\text { standard of financial leverage? }\end{array}$ & 74,4 & 9,3 & 16,3 \\
\hline 4 & $\begin{array}{l}\text { Is the separation of deposit and lending activities and investment ban- } \\
\text { king entities to separate an appropriate instrument of fightback? } \\
\text { Is a tax on bank transactions the right solution for anti-crisis? }\end{array}$ & 67,4 & 23,3 & 9,3 \\
\hline 5 & $\begin{array}{l}\text { - No response } \\
\text { Is the project creation of support fund bankruptcy and reorganization }\end{array}$ & $\begin{array}{l}27,9 \\
(2,3)\end{array}$ & 65,1 & 4,7 \\
\hline & process in the EU founded? & 55,8 & 25,5 & 16,3 \\
\hline 6 & $\begin{array}{l}\text { - No response } \\
\text { Should international rating agencies be subject to international regu- }\end{array}$ & $(2,3)$ & & \\
\hline 7 & lation and supervision of international institutions? & 83,7 & 11,6 & 2,3 \\
\hline
\end{tabular}

Source: Masiukiewicz, P. (2012)

\section{Conclusions}

The list of inefficient and ineffective actions and pathology organization corporates is a long one. Perhaps, two lists could be still identified - one for actors of the real economy and another for financial sphere. Simple methods of reducing the volume of business under the concept of lean management include divestments of assets, outsourcing and offshoring, 
franchising some of its activities, transfer of business to subsidiaries (subsidiary) and segmentation of the company and selling separate parts.

Discussion is focused on the limiting the growth of large corporations' administration. It seems that it provides better economic instruments (such as taxes) and market discipline. The need for greater monitoring of these entities and conduct stress tests of macroeconomic risk is also important. What is needed is an international discussion as state regulation and supervision of large corporations, and how much of market discipline should be implemented. This is particularly important in the financial sector, where there is a risk of over-regulation.

The functioning of global business and global banks, their risks and social costs of bankruptcies require further study and in-depth research.

\section{References}

Cecchetti, S.G. (2012). How to cope Too Big to Fail problem? Bezpieczny Bank, 2: 87-91.

Deloitte. (2013). Duże firmy już nie są odporne na kryzys. Retrieved August 30, 2013 from www.podatki.biz/sn_autoryzacja/logowanie.php5/artykuly/podatki

ECCO. (2006). International Index of Corporate Values Report. Retrieved July 15, 2013 from www. ecco-network.com

Environics International. (1999). The Millennium Poll on Corporate Social Responsibility. Retrieved June 15, 2013 from http://www.globescan.com/news_archives/MPExecBrief.pdf

Freeman, J. (2011) Mega-Banks and the Next Financial Crisis. The Wall Street Journal, March, 21.

Galbraith, J.K. (2005). Gospodarka niewinnego oszustwa. Prawda naszych czasów. Warszawa: MT Biznes.

Gardner, E.P., and Molyneux, P. (1998). Doktryna TBTF - postepowanie wobec bankow strategicznych zagrozonych upadloscia. Bezpieczny Bank, 1/2.

Gup, B.E. (2004). What does Too Big to Fail mean? In B.E. Gup (ed.), Too Big To Fail: Policies and Practices in Government Bailouts. Westport: Praeger Publishers.

Impact of Regulatory Reforms on Large and Complex Financial Institutions. (2010). Washington: IMF.

Kasiewicz, S., Kurklinski, L., and Marcinkowska, M. (2013). Sektor bankowy - motor czy hamulec wzrostu gospodarczego. Warszawa: WIB Alterum.

Knight, F.H. (2006). Risk, uncertainty and profit. Mineola: Dover Publications, Inc.

Kotarbinski, T. (1973). Traktat o dobrej robocie. Wroclaw: Zaklad Narodowy im. Ossolinskich.

Krugman, P. (2009). The Return of Depression Economics and the Crisis of 2008. New York: W.W. Norton Company Limited.

Masiukiewicz, P. (2011). Moral hazard a systemy motywacji w bankowości. Prakseologia, 151.

Masiukiewicz, P. (2012). Ryzyko duzych bankow. Perspektywa Polski. Warszawa: CeDeWu.pl.

Masiukiewicz, P. (2012). Rehabilitation proceedings and company value. In S. Morawska (ed.), Ekonomia $i$ prawo upadlosci przedsiebiorstw. Zarzadzanie przedsiebiorstwem $w$ kryzysie. Warszawa: L Oficyna Wydawnicza SGH.

Masiukiewicz, P. (2010). Międzynarodowe bankructwa i afery bankowe. (ed.). Warszawa: Oficyna Wydawnicza SGH.

Mishkin, F.S. (2006). How big a problem is Too Big to Fail? Journal of Economic Literature, 44(4).

Pasieczny, J. (2012). Patologie organizacji w okresie kryzysu. Zarzadzanie i Finanse, 4(2).

Phillips, T. (2011). Fit to bust. How great companies fail. London: Kogan Page Ltd.

Roubini, N., and Mihm, S. (2011). Ekonomia kryzysu. Warszawa: Oficyna Wolters Kluwer.

Stern, G. H., and Feldman, R. J. (2004). Too Big to Fail: The hazards of bank bailouts. Washington: The Brookings Institution Press.

Stiglitz, J.E. (2010). Freefall. Jazda bez trzymanki. Warszawa: Wydawnictwo PTE.

Stypułkowski, C. (2010). Too Big to Fail - różne koncepcje działań. Bezpieczny Bank, 3: 92-100.

Szygiel, J. (2013). Jak wielki może być bank. Bank, 2. 
Toporowski, J. (2012). Dlaczego gospodarka światowa potrzebuje krachu finansowego. Warszawa: IW Ksiazka i Prasa.

Urbanek, P. (2012). Nadzór korporacyjny a stabilność sektora finansowego. Lodz: Wydawnictwo Uniwersytetu Lodzkiego.

Zygierewicz, M. (2011). Ryzyko systemowe w sektorze finansowy. Zarzadzanie wartoscia instytucji finansowych. Prace i Materialy Wydziału Zarzadzania Uniwersytetu Gdanskiego, 4/5.

\title{
FUNKCINIAI SUTRIKIMAI IR RIZIKA DIDELĖSE FINANSŲ INSTITUCIJOSE
}

\author{
Piotr MASIUKIEWICZ \\ Pawel DEC \\ Varšuvos ekonomikos mokykla, Lenkija
}

Santrauka. Dabartinè ekonomikos krizè parodè, kad net didžiausios kompanijos, milžiniško dydžio verslas ir iš pažiūros neịsivaizduojamas turtas gali žlugti. Autorių mokslinio tyrimo tikslas buvo išnagrinèti valdymo charakteristikas didelèse finansų institucijose ir bankuose ir, atsižvelgiant $\mathfrak{i}$ priimtus kriterijus, pagal prakseologijos teoriją nustatyti pagrindines rizikas ir funkcinius sutrikimus, taip pat rizikos mažinimo priemones šioje srityje. Svarbu pažymèti, kad didẻjanti grèsmè atsiranda dèl egzistuojančios sisteminès rizikos ir tai yra šiuolaikinių finansų rinkų bruožas. Moksliniame straipsnyje išsamiai analizuojami didelių bendrovių teoriniai aspektai ir finansų rinkų veiklos rizika. tūros.

Reikšminiai žodžiai: krizè, rizika, prakseologijos kriterijus, finansų institucijos, didelès struk- 